\title{
Governance in Mongolian Higher Education: A Comparative Analysis
}

\author{
Altangerel Balgan ${ }^{1}$ \\ ${ }^{1}$ University of Commerce and Business, Sukhbaatar district, $8^{\text {th }}$ khoroo, Ulaanbaatar-210648, Mongolia. E-mail: \\ bln_altaa@yahoo.com \\ Correspondence: Altangerel Balgan, University of Commerce and Business, Sukhbaatar district, 8th khoroo, \\ Ulaanbaatar-210648, Mongolia. E-mail: bln_altaa@yahoo.com
}

Received: May 14, 2018

Accepted: May 31, 2019

Online Published: June 3, 2019

doi:10.5430/ijhe.v8n3p185

URL: https://doi.org/10.5430/ijhe.v8n3p185

\begin{abstract}
The author presents some analysis of HE governance in Mongolia in comparative framework. The presentation is devoted to University administration matters, particularly to relationship between Government and HEI, decision making regarding human resources, academic programs and research, setting tuition and fees.

In highly competitive global context the key issues facing Mongolian Higher education are university autonomy, quality assurance, funding, program competitiveness and research effectiveness. Mongolian Government has approved National programs for development of outcome based HE system and research universities.

Mongolian HEIs seeking more autonomy face strong challenges to cope with reduction of funding and accountability. Market oriented policies and demand to sustain a balance of teaching and research, urge HEIs to make a transition from traditional, politically motivated administration to corporate or shared governance models.

The strengthening research links the industry and business without jeopardizing their academic integrity is main challenge for HEIs to make successful transition from traditional background of governance to more effective governance model. According to the author, transformative experiences and organizational developments of HEI in developed countries can be used successfully to guide actions towards positive catalyst change in Mongolian HE.
\end{abstract}

Keywords: higher education governance, market orientation, university autonomy, quality assurance and accountability, corporate management, shared governance, HE competitiveness, sustainable development

\section{Introduction}

This paper provides a comparative analysis of some issues of Higher education administration in Mongolia. Comparative research is productive for understanding a reality shaped by global trends and reforms, and regarded as most promising to extend a single system study.

The analysis proceeds within system levels and belongs to a family of international, transnational studies. Comparative research of HE provides the opportunity to reflect upon phenomena within national HE system through the lens of other systems. Country specific review is defined in the comparative framework.

The author has analyzed policy documents and data of Mongolian Higher education as a Management development plan (1992) and Mongolian Higher education and human resources master plan (1994-1998) which had been developed with support of ADB. Legislative and other policy documents have been analyzed in comparison with policy documents and research reports on HE presented and published by UNESCO, EU and Government agencies of Asian countries.

The recent review of higher education governance highlighted the needs for reforming governance structures and better management in Mongolian public and private HE institutions.

This approach is applied to analysis of the behavior of universities and policy makers and the dynamics within the relationship between universities and the Government agency.

Author examines changes in government policy, in the leadership and management of Mongolian HEIs in comparative dimensions. The study employs basic theoretical ideas and principles and aims to assess application of contemporary governance and leadership models to Mongolian higher education institutions. 


\section{Governance in Higher Education: Concepts and Issues}

Higher education system makes the free competition of the market more powerful in the quasi-market of education. The concept "competition" is based on the combination of cooperation and strategy in the broad spectrum.

Quasi-markets can be examined very differently, especially with regard to the role of governments and to the degree of autonomy conceded to institutions. There are three possible types of relationships between the state and the universities are: control by the state, free market and administration of the universities carried out by 'academic oligarchies' (self-regulation). It is useful to differentiate between two quasi-market general models: the 'Anglo-Saxon' and 'continental' models. (Tomasso. A, \& Giuseppe. C, 2006)

In most of developed countries Governments have reinforced a general trend away from the "state-control model(the continental model)" of higher education towards a "state-supervisory model" including changes in the role of institutional councils from a "control-oriented" function to an "advice-oriented" stance. Nowadays the social activities of the universities are expanding. Public universities are providing the opportunity to obtain education for low income students and minority groups, to advise and support students to meet labor market demands and to increase funding for these activities.

In this context "new managerialism" has become part of the academic world and requires the moves to make HEIs more responsive to social needs, to provide a new impetus for interdisciplinary and multidisciplinary teaching and research activities.

Some researchers have emphasized a significance of New Public Management (NPM) ideas in HE, particularly in public HEIs. NPM is closely associated with Neoliberal approach to HE, enhancing academic freedom and institutional autonomy. NPM - inspired ideas are popular among researchers and leaders taking part in public policy development. Due to the impact of economic factors, governments' policies in many countries focused on tightening the links between higher education and the needs of the labour market for highly qualified employees.

Policy coordination in Higher education requires complex approach to multilevel and multi actor dynamics of Higher education. Comparative analysis of multilevel and multi actor characteristics of HEIs presents system wide and institutional differences in policy making and governance.

UNESCO in 1998 at World Conference on Higher education has announced the fundamental principles for the in-depth reform of Higher education systems in the $21^{\text {st }}$ century. (UNESCO. World declaration on Higher education. 1998). Access on the basis of merit, the renovation of systems and institutions and service to society, the autonomy and social responsibility of HEIs are important areas of the reforms in HE.

In the $21^{\text {st }}$ century HEIs in developing countries of Asia face new challenges reexamining the role of government/state in HE, introducing market mechanism and public-private partnership, decentralization and institution based management, promoting transnational education, targeting quality education, research and innovation in knowledge economy. Global trends of $4^{\text {th }}$ industrial revolution and ICT based innovations have serious impact on Asian Higher education.

In countries with a traditionally more centralized approach to the administration of the HE and research sectors, radical changes to the philosophy of HE management have been nevertheless slowly appeared on the public policy agenda through changes to the administrative rules. (Carrera Suarez and Vinuela Suarez 2005)

The struggle of many universities to advance necessary changes are rooted in the rise of corporate governance. Since many members of university boards of governors are successful entrepreneurs who rose to the top of the corporate world, and some university presidents and provosts serve as a CEOs .

In universities, according to organizational research, centralized power was limited and strong internal governance was mostly absent. Although cross-national variation exists, this pattern can be found in very different national systems.

In Mongolia HEIs were viewed as a key social institutions, and in that's way Government played a central role in regulating HE. In the age of globalization, market competition and need for cooperation has prompted new approaches to higher education. Mongolian Government has prompted a shift to multilevel governance emphasing the coordination by various actors and system levels.

The reforms of higher education governance in recent years have been driven by the international and external pressures. Some remarkable changes have taken place in the university governance systems by enabling legislation with the withdrawal of the state, government from certain control and management functions, devotion of responsibility to university councils and there is the development of new forms of accountability through 
performance and outcome based funding for universities.

Organizational autonomy in Mongolian HE is complicated issue of discussion. Mongolian public HEIs have made a significant move from state control to semi-autonomy private HEIs have more autonomy in organizational aspect. There are some similarities in Higher education institutions of EU.

Executive Leadership in Mongolian Higher education is a matter of political discussion. Facing tremendous challenges of global competition, universities need senior administrators with vision and leadership styles that fit the complex world of postsecondary education. Appointment of Executive Leaders (presidents, rectors) in public Higher education institutions in practice is a prerogative of Government agency (Ministry) despite it is a prerogative of Board of trustees. In public higher education academic community seeks more power to appointing executive leaders. In private HEIs an appointment of presidents is privilege of Board of trustees.

In Mongolia Institutional leaders make decisions being closer to stakeholders despite attempts to increase the autonomy and self-regulation of universities. Changes in HE governance require some degree of consensus to be found between the conflicting "corporative interests".

Policy makers in Mongolia and other countries have to deal with political arrangements, socio-economic context and dynamics of globalization. Changes in Mongolian HE have been pursued by Government to improve systemic performance through the redesigning rules of the game for HEIs to assume more perspective regulations and renewed governance regimes.

In many countries HEIs have developed shared governance model through common vision and collaboration. Mongolian Government in 2018 has approved National policy for Outcome based Higher education. (National policy for outcome based higher education. 2018). According to Government policy, shared governance announced in above named National program, is more effective way to reconstruct governance of HEIs in a positive way for the future. In Higher education shared governance is divided in some ways. It is common to find the faculty charged with the design, oversight, and teaching of the curriculum, with some minimal level of input from administrators. Virtually all other matters - co-curricular programming, student life, and, above all else, decisions about the spending off institutional money - are the purview of administrators, with some minimal level of input from faculty. The necessary tensions between these horizontal and vertical elements sustain complexity in institutions of HE. The vertical and horizontal structures vary in number and dimensions from country to country. Student services have the horizontal nature. The horizontal force finds its roots in accountability for students learning outcomes, research intensive programs. Coupling of horizontal and vertical schemes in academic activities is a common tendency in most of HEIs.

Highly interrelated elements of the university as an organizational actor can be distinguished, in very different national settings. The most visible sign of this is the development by universities of "mission statements".

In the era of the $4^{\text {th }}$ industrial revolution decentralization of HE governance at system level has direct relation to CPS (cyber physical systems) and digital transformations creating high degree of flexibility and virtualization of supply chains in HE. ICT based training and learning has created the neuro-interface as a brain-educational space making shorter life cycles of academic programs which means serious changes on academic administration of HEIs.

\section{Higher Education Autonomy: Common Issues and Differences}

Institutional autonomy and academic freedom are most important challenges facing Higher education in 21st century.

The degree of autonomy of HE institutions is classified into three levels: full autonomy, partial autonomy or regulation totally by the public authorities. (Tommaso Agasisti, Giuseppe Catalano 2006.)

In developed countries a degree of autonomy of public HEIs depends on National regulation framework and funding schemes, Governments provide greater autonomy to research and public universities by decreasing the funding. In developing countries financial autonomy of HEIs is strongly limited.

In some European countries, governments initiate a middle "buffer system" to fund universities. In Mongolia, Government has established buffer agency to offer financial assistance and loans to students. In European countries, universities use grants and budgets based on operational expenditure which are funded by the Governments. In Mongolia government buffer agencies as Innovation fund, Science and technology fund offer financial assistance to university-based research projects. These middle buffer schemes assume partial autonomy of Mongolian HE in funding. In terms of funding and accountability in Mongolia policy makers need to a change from earmarked spending to lump-sum or block-grant budgets, a move towards the introduction of more objective funding procedures, 
connecting the funding to outputs (degrees awarded, publications) rather than inputs (enrolled students) and the development of external, contract-based funding. There is a lot of discussions about setting effective financial mechanism as quality based, outcome-based or scholarship-based funding.

The access to HE and quota of places in HEIs, funding models are closely connected to Government policy, market demands, the employability of graduates and degree completion rates. Some dilemmas about equity, access and cost of higher education bring to highlight reflection on the educational policy. Equal access and quality as two sides of social responsibility are considered in admission quota. In Mongolia allocation of funds to public Universities and enrolment criteria for all public and private HEIs are used as an instrument of higher education accountability. But a question about performance based funding of $\mathrm{HE}$ has pointed to a lack of openness and incentive mechanisms.

Mongolian HEIs also have more autonomy in setting admission quota, Ministry of Science, Education and Culture and Sports only have determined basic criteria for graduates of high schools to apply to HEIs. But in practice opportunity for applicants to be admitted to HEIs is determined by their financial possibilities, quota of tuition loans offered by buffer funding agency.

Mongolian HEIs have the autonomy in recruiting of faculty and staff, setting tuition fees. But offering new programs is matter of regulation in the framework of special procedures set by Ministry of Science, Education, Culture and Sport and National accreditation agency.

Mongolian government has developed policy to make HEIs more accountable by increasing their autonomy. Idea is that HEIs need to ensure real change in their management, to impose an effective method of evaluation, to make academic and funding process more open in all respects. Increased autonomy of HEI has positive effects on participation of faculty in institutional governance, an efficiency and quality of HEIs.

Academic governance models vary across universities. Representative bodies of the academic community, sometimes including students are typical in HEIs. Decision making in HE is complex process of balancing the needs and interests of HEIs and market, HEI administration, faculty, students and general public.

Participation of faculty in university administration is gone through university Academic council consisted from representatives of faculty and researchers.

In Mongolia HEIs faculty members participate in decision making in following areas as development of the curriculum, subject matter, methods of instruction, and academic standards and processes. Students' involvement in decision making regarding academic programs and setting tuition/fees is a matter of discussion.

The findings showed that increased autonomy has improved freedom in curriculum development, course design, research priorities, and academic programmes, clearly indicating that increased autonomy significantly benefits the development of academic fields. There is increasing concern for leadership in academia, collegial participation of the overall professoriate as powerful decision-makers.

In decision making are number of challenges for main actors of HE. In the loosely coupled-system traditional decision-making structures within universities are becoming increasingly hierarchical at the overall levels of the organization.

The traditional European model of control by the senior professors, who also have to elect the rector from among their ranks for short terms of office, is perhaps no longer practical, in light of the myriad skills demanded of an effective university leader. Research universities especially need the full involvement of the academic staff in the key decision-making arrangements of the institution. Research universities typically have a greater degree of professional power and stronger guarantees of academic autonomy than other academic institutions. Knowledge intensive industry and business innovation lead to multi-actor governance and diversification of academic and research programs in Mongolian HEIs.

National program for research based entrepreneurialism and new commercial environment for research have been painful to the academic traditions. Leaders of HEIs seek for more effective ways to foster entrepreurialism and research based innovation, to diversify revenue sources. In this connection Mongolian HEIs and research institutions need to develop mutual cooperation, to concentrate human and financial resources in most important priority areas of National economy and industry. Many Mongolian HEIs face challenge to make successful transition to involvement in research links with the industry and business without jeopardizing their academic integrity. (National program for research based university development, 2018).

These changes in Mongolian HE governance require quality assurance procedures with focus on autonomy and accountability. Accountability which traditionally has been much more individualized now is transferring into 
organizational structure. Accountability of HEIs in closely related to a Quality Assurance in Higher education. Quality of programmes and research, competitiveness of graduates, effectiveness and efficiency of funding mechanism are basic criteria of HE accountability. Seeking more autonomy HEIs face strong challenges to cope with reduction of funding and accountability. There is important to advance transition from politically motivated administration to valued leadership in Higher education. Limitation of centralized power and strong internal governance in different national settings are the object of analysis for researchers and policy makers.

\section{Impact of Globalization on HE Governance}

Under pressures of globalization HEIs have transformed into a product exchangeable at an open market. Educational products of all kinds would be freely exported from one country to another. Copyright, patent, and licensing regulations, already part of international treaties, would be further reinforced. It would become very difficult to regulate the trade in academic institutions, programs, degrees, or products across international borders.

The World Trade Organization (WTO) is considering a series of proposals to include higher education as one of its concerns, ensuring that the import and export of higher education be subject to the complex rules and legal arrangements of the WTO protocols and free of most restrictions.

There is strong challenge for academic systems or individual universities to independently develop in the increasingly competitive and fast-moving global higher education scene dominated by the world-class universities in the industrialized countries.

The interplay between international and national forces in the shaping and developing of National policies on HE presents an actual interest for decision makers and leaders of HEIs in Mongolia.

With respect to new developments in globalization of higher education, Mongolian HEIs promoted effective incentives for quality assurance and accreditation in international framework. Demand to improve a competitiveness of Mongolian HEIs leads to sustainable development in HE of internationally recognized quality dimensions and transformative environment. Processes of globalization impose transnational approach to quality assurance. Accreditation service offered by International agencies as ACBSP presents an effective way improve a quality of HE in Mongolia. Quality assurance in the International framework must create solid basis for international transferability and recognition of national certificates and qualifications.

Global partnerships in HE lead to the specialization of work which is reflected in various satellite education and research centers, restructuration of professional work into mobility teams of professors with limited obligation, contingent contracts. Most developed countries of Asia, Japan and Korea have focused on expert of HE programmes and research products. There has been a marked increase in the number of double or joint degree programmes. HE hubs, satellite campuses present an example of global partnerships in Asia.

In most Asian countries as China, Singapore, Thailand, Malaysia, Vietnam transnational programmes and satellite campuses of foreign universities have introduced significant changes in Higher education organizational structure creating regional hubs of Higher education and developing collaboration with multinational enterprises. ASEAN credit transfer system is important initiative in HE internationalization in Asian region.

The internationalization of the curriculum, joint and double degree programmes leading to foreign degrees, and implementation of the project 211 to developing world class universities are important areas of reforming HE in China.

For Mongolian HE internationalization is an effective way to integrate an international dimension into University academic and research activities. Major form of internationalization are joint double degree programmes leading to foreign degrees, students exchange and transnational approach to curriculum development and program accreditation.

In the age of globalization, Mongolian HEIs in response to demand for increased economic relevance and wealth creation, and demand for more social relevance develop bilateral and multilateral cooperation with HEIs in Asia-Pacific region, EU and USA. Main areas of cooperation are alignment of higher education systems and policies, development of cross-border collaborative programs, establishment of qualification framework, and credit transfer systems in order to facilitate regional harmonization and talent mobility.

Approaches to internationalization ranging from market reliance for centralized intervention with government regulations vary among countries. In this connection HEIs need to combine different approaches in institutional strategy. 


\section{Conclusions}

The findings of comparative research showed that in Mongolia major changes caused by increased autonomy, tended to identify following areas: academic programmes, faculty and staff management and evaluation, admission and management of students services, administrative procedures, decision-making structures, and financial management.

Academic changes taken place in Higher education has been provoked by transformations under pressures of globalization and needs to improve competitiveness of Mongolian HEIs in international dimensions.

Globalization has impacted differentiation within national Higher education systems. Socio-economic environment, competition for resources and academic norms are initial conditions affecting differentiation in Higher education.

New challenges call for more study of Mongolian HE governance in the framework of globalization and new social economic realities. Internationally recognized quality dimensions and transformative environment support in Mongolian HE platforms for knowledge sharing and networking, developing value-added academic and research programs, fostering competitiveness of national HEIs through collaboration.

\section{References}

Andrew, P. (2004). University Governance and Autonomy Problems in Managing Access, Quality and Accountability. Simon Fraser University. Retrieved from www.sfu.ca/content/sfu/pres/presidentspeeches.20045.html

DeSocio, W. G. (2012). Future Trends in Higher Education Board Governance. University Business Magazine, UB. Booklet. Remodeling Higher Education Board Governance.

Feuvre, N. L. (2005). Disciplinary Barriers between the Social Sciences and Humanities. The Impact of the Relationship between the State and the Higher Education and Research Sectors on Interdisciplinarity in Eight European Countries. Comparative Report, The University of Hull, European Union, France. 9-10

Fielden, J. (2008). Global Trends in University governance education . Working paper series Number 9.

Jonathan. W, S. (2013). Conceptualizing the Shared Governance Model in American Higher Education: Considering the Governing Board, President and Faculty. Journal Social Sciences, Arts \& Humanities, 5(12).

National Policy for outcome-based Higher Education. Resolution of Mongolian Government. (2018). UB

National Program for Research based University development. Resolution of Mongolian Government. (2018). UB

Nokkala, T. E. (2009). University autonomy in Europe. European University Association, EUA publications. 15-17

Robert, A. (2010). The "In Idea of a University" today . $H \& R$ papers .

Roger. W, B. (2006). Institutional Autonomy, Academic Freedom \& Academic Responsibility. General Secretary of the American Association of University Professors (AAUP). The Montana Professor, 17.1. Retrieved from http://mtprof.msun.edu

Tommaso. A, \&. G. (2006). Governance Models of University systems-towards quasi market: An European comparison. 28, 245-262. https://doi.org/10.1080/13600800600980056

UNESCO. (1998). World Declaration on Higher Education for the twenty-first century: Vision and Action and Framework for priority action for change and development in Higher Education. World Conference on Higher Education . Paris.

University autonomy under fire . (2015). The Japan Times.

Yojaha. S. (2012). World Bank calls for university autonomy, quality research . University World News Asia Hub. 